\section{Milica Đokić ${ }^{1}$}

University of Nis, Faculty of Economics
SCIENTIFIC REVIEW ARTICLE doi:10.5937/ekonomika1801079D

Received: December, 07, 2017

Accepted: March, 12, 2018

\title{
THE ROLE OF INFORMATION AND COMMUNICATIONS TECHNOLOGY IN INTERNATIONAL TRADE
}

\begin{abstract}
Many previous studies have proved that revolutionary progress and breakthrough of information and communications technology (ICT) has had a tremendous significance for the development of international trade. The purpose of this paper is to present some of the major channels through which new information technologies impact international trade flows. In addition to various benefits of e-business for the exchange of information, products and services, some of the key challenges are also indicated. Unauthorized access to confidential information, misuse of users' personal data, insufficient availability of broadband connection and restricted access to it are just some of the problems that need to be overcome in order to maximize the benefits of technology in international trade.
\end{abstract}

Key words: international trade, information and communications technology, e-commerce, Internet transactions, electronic payment system, data protection

JEL Classification: F1,03

\section{УЛОГА ИНФОРМАЦИОНО-КОМУНИКАЦИОНИХ ТЕХНОЛОГИЈА У МЕЪУНАРОДНОЈ ТРГОВИНИ}

\section{Anстракm}

Бројне досадашње студије су доказале да је револуционарни напредак и продор информационо-комуникачионих технологија био од огромног значаја за развој међународне трговине. Сврха рада јесте да прикаже неке од основних канала преко којих се утицај савремених информационих технологија испољава на међународне трговинске токове. Осим бројних предности у размени информација, производа и услуга, указује се и на кључне изазове које дигитално пословање доноси. Неовлашћени приступ поверљивим информаичјама, злоупотреба личних података корисника, још увек недовољна распрострањеност брзе, стабилне интернет мреже, као и слаб приступ, само су неки од проблема које треба превазићи како би се максимално искористио сав потенцијал технологија у међународној трговини.

Кључне речи: међународна трговина, информационо-комуникационе технологије, е-трговина, интернет трансакиије, електронски системи плаћања, заштита података

\footnotetext{
${ }^{1}$ milica91nis@hotmail.com
} 


\section{Introduction}

New technologies have significantly changed the way people communicate, work, live... There is almost no area unaffected by them. The significance of information technologies for business development and economic growth is tremendous. New technnologies have provided organizations with many possibilities and benefits, such as highly automated business processes, lower costs, new products and services, and new ways for making transactions and interacting with clients.

In a modern globalized business environment, trade is under the dominant influence of information and communications technology. Familiarizing with the foreign environment has never been easier, and entering new markets has never been cheaper or faster. Communication and connection with international business partners have been made significantly easier and the role of global supply chains in international business is getting more and more important. Innovative technological solutions have enabled organizations to overcome physical barriers and gain access to a large number of markets, expand their consumer base, improve communication with them and realize high profits in much shorter periods of time. This has created a much stronger competition in the global market and caused the need for a constant improvement.

Conducting commercial transactions online is becoming highly common, both in the business of companies and in everyday lives of people. The expansion of mobile devices and wireless Internet access have enabled the exchange of data, products and services at any time, from any location, while the development of electronic payment methods has enabled fund transfer and efficient completion of transactions.

In addition to many advantages, the development and the increasing use of modern technologies in trade have also caused many new problems that need to be overcome. Mass digitalization of data, the expansion of global networks and the increasing Internet speed have enabled unauthorized access to large amounts of data and systems. There is a growing need for privacy protection of Internet users and for safer methods of payment. Despite the expanding use of the Internet, the difference in the level of technological progress between developed and developing countries is still enormous, which represents a significant obstacle for further stimulation of international trade and their participation in it.

\section{The impact of information and communications technologies on the formation of international trade flows}

In the modern society the most important resource is information, and the application of new technologies is often a necessity in performing everyday activities. This kind of society, in which information and communications technology plays a key role, is often called information society. It is a society characterized by a very high intensity of information in the everyday life of the majority of people and in most organizations, or business systems; a society characterized by the use of general, or compatible technologies for an easy and efficient realization of a wide range of personal, social, educational and business activities; a society characterized by exceptional possibilities 
of quick reception, sending and sharing of digital data, whereby geographical locations and distances don't matter at all (Đorđević, 2012). The breakthrough of information technologies and the wider availability of the Internet have made a lasting impact on the economies of countries around the world and on international trade. More and more transactions are conducted electronically and new, innovative business models are constantly evolving.

During the past two decades, the progress of information and communications technologies and the development of new logistics solutions have considerably contributed to the shaping of the global economy. Methods for the production and distribution of products have significantly changed, and global supply chains have been given a leading role. This trend has been followed by an increasingly diversified service sector, whose share in the world output has become much larger. All these activities have occurred internationally, their implementation has been greatly dependent on available information and they have been relying heavily on innovative means of communication. The Internet brought about the most notable revolution, completely changing the methods for the production, distribution and use of products and services. It has made a lasting impact on all spheres of society.

Many studies dealing with the assessment of the impact of new technologies on international trade in goods and services have clearly shown that open access to the Internet, good technological infrastructure and intensive use of information and communications technology have had a positive influence on export of individual countries, as well as an enormous impact on the overall volume of world trade (Freund, Weinhold, 2004; Clarke, Wallsten, 2006; Vemuri, Siddiqi, 2009; Choi, 2010). Considering its undoubted contribution to exports, the use of information and communications technology has proved to be of great importance to emerging market economies and developing countries that are trying to promote international trade (Lui, Nath, 2013).

Most recent researches only confirm the previous results. One of the studies that included 51 countries, 30 OECD member countries and 21 medium and low-income countries indicated that better access to modern information and communications technologies and e-commerce applications boost bilateral trade flows among different groups of countries (Xing, 2017). Results implied that the Internet penetration and adoption, number of broadband subscriptions and secured servers greatly affected the trade among the observed groups, the so-called Southern and Northern economies. Moreover, it was found that having a reliable and stable internet connectivity, as well as encouraging the wider use of digital technologies are preconditions for the inclusion of a group of African countries into global trade flows. The results of the study also highlighted the great potential of e-commerce in least developed countries and developing countries. Nevertheless, in order to fulfill that potential, many of them primarily have to improve their technological and transport infrastructures, to establish effective procedures for conducting electronic transactions, and to work on educating and training their citizens for the use of modern technologies and digital business. One of the studies dealing with the impact of new technologies on international trade investigated whether international trade is more influenced by the number of subscriptions (quantity) or data flow speed (quality). The analysis included developed and developing countries. The results showed a positive correlation between exports with both ICT quality and quantity, as well as that in developing countries the bandwidth speed quality is more important than the number 
of subscriptions (Abeliansky, Hilbert, 2017). This can be explained by the fact that, although an increasing share of the population is using the Internet, the data flow speed in these countries is still not stable, and the inability to communicate and exchange data at the speed required by the global environment can hamper or prevent the participation of these countries in international trade. Regarding imports, the impact of the ICT quantity and quality is larger in developed countries than in developing countries, whereby the rise in the number of subscribers leads to a higher level of imports. Such a result indicates that the existence of a reliable and stable Internet connection allows access to an incomparably wider range of products and services, giving consumers much more choice, which ultimately leads to a higher demand for foreign products.

\section{The significance of technological development for international trade}

High costs are one of the main characteristics of international trade and often represent a greater obstacle to exporters than certain trade measures. Entering new markets has always been a big challenge for companies, both because of the unknown environment and high entry costs. Undertaking any business activity in a foreign environment always involves a great degree of uncertainty, which additionally complicates the planning process. Such uncertainty is often caused by having insufficient information and by the late obtainment of necessary information. Collecting all relative data on the new market and its specificities, and adjusting means of advertising and distribution methods to the given conditions represented a formidable, and for many business entities, an insurmountable obstacle. The development of modern information and communications technologies, especially the global Internet network, has facilitated the process of acquiring relevant information about new markets and enabled access to an enormous number of consumers, with much less money and time spent. Finding appropriate suppliers, determining the price, promoting products, arranging deliveries and many other activities can now be carried out without the need for a buyer and seller to meet personally. Considering that technology reduces the costs of entering new markets, Internet expansion has unambiguously contributed to the growth of exports (Freund, Weinhold, 2004). In addition, the role of modern technologies in international trade of services has become increasingly important over the years, especially with those services that are based on the creation, processing and transmission of information.

Increasing diffusion and use of information and communications technologies has led to higher volume of the world trade through various channels. The novelties in distribution methods have significantly reduced transport costs, while the use of radio waves, identification tags and the Internet has enabled product movement tracking at any time. This has significantly improved logistics and contributed to the development of a more efficient multimodal transport system. The costs of obtaining and exchanging information and communicating have been further reduced. With the development of the telecommunications and Internet networks, all participants in the international trade have been given the opportunity to obtain information in a much simpler and cheaper way. The Internet has taken the lead in communication at the global level, and the appearance of wireless networks and mobile devices has significantly contributed to that. This has 
allowed a large number of smaller companies, whose business had been limited to local markets by then, to engage in international trade. The Internet provided the opportunity for companies of all sizes to access the world market in a completely new way and envolve in international trade, which was once possible only for powerful multinational companies. Since some branches of trade are more dependent on information than others, the benefits derived from lower costs are not always the same. It is not surprising that higher savings were made in the sectors of technologically advanced products than in agricultural sectors, for example. Besides that, a large number of products that once existed in physical form and demanded physical delivery can nowadays be found in digital form. Various texts, from the most famous works of world literature, to scientific articles, popular magazines and the latest publications, are now only a few clicks away, without the need to go to a library, a bookstore or a newsstand. Music, movies and computer programs are just some of the examples of goods that are now much more easily delivered digitally. With such products, the development of e-commerce has led to a significant increase in the volume of transactions. On the other hand, when it comes to products that do not exist in digital form, shipping costs still play a major role. In these cases, it is possible to obtain all relevant information about product characteristics on the Internet, to get familiar with user experience, and even make payments, but due to physical delivery, its final price largely depends on the costs of transport and customs duty.

Besides the trade of final goods, new technologies have also contributed to the rapid growth in the international trade of raw materials, parts and components, with the fast development of global supply chains. Cross-border coordination of different entities in global supply chains has become considerably more efficient because of the quick exchange of information without delay and easier communication. Therefore, it is not surprising that products, especially products of higher degree of complexity, are rarely produced entirely in one country. High quality raw materials can be acquired in the regions where they are sold at the best price, the production of parts can be done in factories with the most advanced technology, even if they are in another continent, and the product assembly process can be performed in countries with the lowest labor costs. All these activities can be easily organized and conducted with modern information systems, although they are often performed in different parts of the world, which was once almost unimaginable. However, in some sectors, the technology progress, and especially the development of e-commerce, has led to the elimination of certain participants in supply chains. Producers very often get in direct contact with consumers, skipping some of the intermediaries such as distributers and retailers. Manufacturers can independently sell their products, without the need to use retail or distribution channels, by providing consumers with all the necessary product information and by enabling direct ordering. On the other hand, there are branches of trade in which the intensive use of technology has contributed to the emergence of completely new professions that did not exist before. Thus, new types of intermediaries have been created, specializing in providing help to the Internet users in gathering the desired information, locating products, etc.

Most companies nowadays rely on virtual space as a key platform for promotion. The Internet has become a very powerful tool in international marketing because it provides a rich source of information about the desires, needs, habits and behavior of consumers that can vary significantly depending on age, geographical location, customs, 
religion, and many other factors. Such information is a valuable resource that merchants can use to adapt all elements of marketing mix to the target market and achieve a significant advantage over competitors. For example, Chinese consumers apparently pay much attention to video content, therefore, this type of promotion is recommended for succeeding on the Chinese market. It is difficult to conduct market segmentation by using traditional means of advertising, such as billboards, newspapers and television (Spulber, 2010). The Internet enables companies to obtain a wide range of information about the interests, needs, and expectations of different groups of their customers, therefore marketing activities can be targeted in a more efficient way at smaller market segments, and even at individuals. And when the content of promotional activities is specifically tailored to the preferences of individual customers, it is more likely that each of them will get exactly what they are most interested in, and therefore the chances of making a purchase are much higher. For these reasons, a large number of companies use personalization technologies on their websites to create web pages with content and banner ads focused on the specific needs of a particular visitor (Jovanović, Milovanović, 2008). Moreover, many companies allow their customers to design products themselves, according to their needs. Product customization is becoming a common method that companies use in order to achieve a competitive advantage. By providing a basic platform of products that can be modified with desired additions, or designed in a special way, companies are enabling customers to buy unique products. In this way, manufacturers are able to respond more effectively to the needs of each consumer individually, thus possibilities of selling are significantly higher.

\section{E-commerce}

The power of the Internet is reflected in its huge number of users. Namely, by mid2017, the number of people who have a permanent access to the Internet has exceeded half of the world's population and amounts to just over 3.8 billion $^{2}$. They all make up a huge base of potential consumers whom manufacturers and vendors had never been able to reach easily in the past. Therefore, spatial constraints no longer exist, almost every company has the entire global market at their disposal. This provides many opportunities and chances for realizing higher profits, but at the same time it significantly increases the competitive pressure. While individuals and firms used to be mainly connected with the nearest markets and stores, in the Internet era everything is different. Merchants can offer their products to all Internet users, regardless of where they are, whether they are nearby or at the other side of the world. On the other hand, customers are no longer confined to the offer of local producers, but they also get access to the products of regional and world companies, so the choice is incomparably greater.

There are many definitions of e-commerce, but the base of each of them is that e-commerce is carried out with the help of information and communications technologies. It can be said that it represents the usage of global Internet for purchase and sale of products and services, including after-sales services and support (Treese, Stewart, 1998) or that it represents the delivery of information, products/services and payment via

\footnotetext{
${ }^{2} \mathrm{http}: / / \mathrm{www}$. internetworldstats.com/stats.htm
} 
telephone lines, computer networks or any other means (Kalakota, Whinston, 1996). The Organization for Economic Cooperation and Development (OECD) defines e-commerce transactions as the purchase or sale of goods or services that are conducted through computer networks using methods designed specifically for the purpose of receiving and making orders. Goods and services are ordered by these methods, but payment and delivery do not have to be done online (OECD, 2011). Nowadays, e-commerce is an integral part of everyday life, especially in urban areas. In this way, people can buy almost everything, from foodstuffs, clothing and footwear, to securities. By examining the structure of online shopping, we can see that the most popular categories are electric appliances, clothes, books, music, video games, as well as beauty and personal care products.

According to the latest Ecommerce Foundation report, which is based on the data for the first quarter of 2017 and includes 22 countries, global B2C e-commerce sales are expected to reach 1.84 trillion US dollars this year. The largest turnover in e-commerce was recorded in China, amounting to more than $\$ 681$ billion, followed by the United States with a turnover of \$ 438 billion and the United Kingdom with \$ 196 billion $^{3}$. Although online shopping is becoming increasingly popular in Serbia, our country is lagging far behind other countries in Europe and in the rest of the world. Consumers in Serbia use the Internet more often to search for and collect the necessary information about products, to compare prices and find store locations, while the process of purchasing is performed exactly in brick-and-mortar stores. Nevertheless, surveys show that there is an increasing number of customers who are willing to spend more money on online shopping in the future. One research conducted by the company Gemius on e-commerce in Serbia has shown that goods which are mostly purchased online in our country are clothes and accessories, technical equipment, sports equipment, books, films, music, computers and other computer equipment. Respondents stated that some of the reasons why they prefer this type of shopping are home delivery, large product assortments, the possibility to compare products of different manufacturers, working hours of online shops that are open 24 hours a day, as well as buying from the comfort of their home, without the need to go to the store. On the other hand, the major problems that domestic customers faced in online shopping were high delivery costs, incorrect product information, products not meeting the expectations of customers and long delivery time. The most common reasons why many consumers still do not want to shop online were the need to see the product before making a purchase, skepticism towards product warranty, and skepticism towards payment methods.

The development of the Internet and e-commerce has influenced the emergence of new business models, and new forms of organizing the offer of goods and services are appearing. In addition to the virtual stores of manufacturers, which are no longer a matter of prestige but a necessary segment of business, in recent years there has been an increasing number of Internet portals and intermediaries providing information, connecting sellers and customers and selling or purchasing products/services. Some online shopping sites offer various product categories of different manufacturers (e.g. Amazon), while there are also specialized online stores that offer only a specific group of products, then there are also online auction sites (eBay) where both companies and

\footnotetext{
${ }^{3}$ Global B2C Ecommerce Report Light 2017
} 
individuals can buy and sell products and many other. At the beginning of the $21^{\text {st }}$ century, the significant growth of e-commerce was primarily a result of its high share in developed countries, while in recent years, the highest growth rates in this type of trade have been achieved by developing countries.

In recent years, new trends in e-commerce have emerged. While online shopping was a real revolution, allowing customers to make purchases on their desktop computers without having to go to stores, now making transactions in this way is not enough and greater mobility is required. For this reason, buying and selling via wireless devices such as phones, tablets and laptops has taken a dominant role over the past years. Such a trend is primarily the result of the rapid expansion of smartphones, as well as other mobile devices that have wireless Internet connection, which enable individuals to make transactions at anytime, anywhere. In the past, mobile phones were mainly used for searching for and gathering information about products, finding nearby stores, and learning about the experiences and ratings of other users, but today they are more often being used for making purchases. Thanks to certain mobile applications, this process can now be performed in a very simple way, with just a few clicks. Moreover, many retailers use QR codes in their brick-and-mortar stores in order to inform their customers about the store, brand and products. Some watchmakers like Omega place QR codes on storefront windows and provide the opportunity for all interested passers-by to scan the code for a particular product and thus get detailed information about it or order it. M-commerce creates new ways for manufacturers and sellers to reach customers, provides an opportunity to achieve constant interaction and a chance for personalization. The development of mobile banking, which allows the transfer of funds and payments from the user's wireless device, has further contributed to the growth of this type of trade. Japan, one of the technology leaders in the world, stands out as a country where about half of the total number of electronic transactions is conducted via mobile phones and tablets, while in Brazil, this type of e-commerce has a share of more than $50 \%$.

Social media are becoming increasingly important online shopping channels. According to the results of the research on the current trends in online shopping, conducted by the company $\mathrm{PwC}$, as much as $78 \%$ of customers admitted that social media influence their buying decisions in certain way (PwC, 2016). Interaction with favorite brands on social networks and other websites has a positive impact on a large part of consumers, who show greater respect for the brand and appreciate the brand even more. Ratings, comments and experiences of other buyers, as well as promotional offers and advertisements have the greatest influence on customers. Nevertheless, the number of consumers subject to these influences varies considerably from country to country. In developing countries this percentage is significantly higher than in developed economies. For example, in Denmark and Belgium, only $22 \%$ to $23 \%$ of respondents paid attention to the opinions and ratings of other customers while online shopping, whereas in countries such as China, India and Malaysia, this figure exceeded $60 \%$. The age of consumers is also an important factor, according to this research. Namely, the influence of social media on the behavior of younger generations is much stronger and weakens significantly after the age of 45. From that point on, consumers also interact much less with their favorite brands on social media. Customer reviews and comments not only affect the behavior of other online customers, but can also be of great importance to retailers. In this way, they can obtain much relevant information about the experiences of their customers, 
which can help them improve their business. By considering the comments, praises and observations of their customers, they can identify the shortcomings of their offer more effectively and find the best solutions for satisfying the needs of their customers.

The development of e-commerce has caused the increase in service trade. While the sale/purchase of products on the Internet usually involves physical delivery (except for digital products), geographical location has no impact on trade in services and the entire process can be completed in a virtual space. Services trade has previously been largely limited, since the provision of most services required physical contact between the service provider and the customer, which represented a huge obstacle to international trade. With the development of new technologies, especially the Internet, such obstacles have been successfully overcome.

Depending on the place and role of information and communications technologies, services can be broadly divided into two categories (Nath, Liu, 2017). The first category refers to services that directly involve the use of new technologies and are often referred to as services enabled by information and communications technologies. Unlike them, there are also services in which information and communications technologies have only an indirect or secondary role. In the first group of services, information and communications technology has affected trade in many ways. The expansion and development of technologies has allowed companies to provide services to consumers at any time, no matter where they are currently located. The exchange of information from different locations around the globe, unlimited communication with business partners and the ability to provide services at any time, without delay, have led to significant changes in global supply chains, which are becoming continuously more fragmented, with activities and processes that are sometimes performed in places on the opposite sides of the world. In this way, the whole production process becomes much more efficient, and significant cost savings can be achieved. There is an increasing number of companies specializing in the provision of particular services, so outsourcing certain tasks in international business is more frequent than ever since it provides a cheaper and faster performance of those activities than completing it internally. In addition, due to the constant development of technology, there is a need for new types of services that haven't existed before, which results in the emergence of completely new service sectors that are becoming involved in international flows. The technological boom hasn't bypassed the traditional services sectors either. Therefore, major changes have occurred in the way of providing transportation, travel and many other services, especially in international environment.

One of the first studies dealing with the role of the Internet in international service trade has proven that the impact of the Internet has been positive and significant. (Freund, Weinhold, 2002). This research has shown that the development of information technology has stimulated the services trade of the United States with countries overseas, especially when it comes to services based on the processing and transmission of information. The results of recent studies have only confirmed the importance of information and communications technologies for the service sector. By analyzing data on imports and exports of 49 countries for the period from 2000 to 2013, which included ten most important service items ${ }^{4}$, it has been concluded that the development of information

\footnotetext{
${ }^{4}$ Audio-visual services, computer services, construction services, financial services, insurance services, other business services, royalties and licence fees, communication services, transportation and tourism.
} 
and communications technologies has significantly contributed to the international trade of seven (out of ten) types of services (Nath, Liu, 2017). It has been confirmed that technology has a considerable impact on imports, exports and the total volume of trade in the financial services sector and in the sector of other business services. It may be surprising that in the field of audio-visual services and computer services, the impact of technology has been considerably weaker, although these services belong to the group of services enabled by information and communications technologies. In contrast, transportation and tourism are traditional sectors in which new technologies have only a secondary role, but they have significantly influenced the volume of trade in services, primarily by reducing transaction costs and facilitating entry into foreign markets. From all the analyzed indicators of technological development (use, access, skills), the use of information and communications technologies has had the greatest impact on imports, exports and the total volume of trade in service sectors. Therefore, the results of this study indicate that strategies and measures used for introducing new technological solutions and for stimulating their use will contribute to the growth of trade in services in most sectors, while easier access to the Internet and the development of necessary skills will primarily affect those services that are more dependent on new technologies.

\section{Electronic payment systems on the Internet}

One of the key segments of every trade transaction is payment. Changes in business and international trade and new ways of buying that have resulted from technology development have created a need for different payment methods. Making transactions online, between partners located at different locations, would be difficult without the electronic transfer of funds. Because of this, modern online payment methods are expected to ensure a fast and secure money transfer. When shopping online, payment can be made in several ways. When it comes to products that are physically delivered, even though they are purchased in a virtual store, there is still the option of paying by cash on delivery. Nevertheless, the majority of transactions on the Internet are made by online payment, and various electronic payment systems have been developed over time.

The most common way of electronic payment is payment by credit and debit cards. Since they are very easy to use, they are widely accepted as the most common method of payment. In order to enable the payment of their products in this way, companies must open a bank account and implement an appropriate information system that will connect them with a financial institution or provider of this type of service. If a customer opts for this payment method when shopping online, after they enter the requested information, the data gets exchanged, the system checks the balance of available funds, approves or denies transfer and informs the customer about the final outcome. All this happens in just a few seconds. In recent years, there has been a slight decline in the use of credit cards, due to the development of other methods that are becoming increasingly popular. Prepaid cards are another category of cards that can be used for paying online. They are mostly used by costumers who do not have open bank accounts and, unlike with credit cards, funds must be added to the card in advance. Payment vouchers are another type of these cards that consumers buy before the transaction.

E-wallet can be seen as a digital equivalent of a physical one (Lupu, Mual, van Stiphout, 2016). It stores all necessary information about the owner and his financial 
funds. It enables an efficient online payment since the user is not required to enter their personal data, credit/debit card information, delivery address, etc. for each transaction. Once the data is entered, electronic wallet transfers them automatically every time a customer makes a purchase. The fact that they can also be used on mobile devices makes them even more convenient. These mobile wallets function like cards, enabling payment in stores. According to some surveys, this method of payment is the most common among Chinese consumers, and it is estimated that in a few years it could take over the dominant position in other parts of the world.

Online banking e-payments, or bank transfers, are considered to be one of the safest methods of payment. At the moment when the customer starts the process, the financial institution immediately checks their identity and the availability of funds and if the transaction can be approved, the merchant immediately receives a guarantee that the funds will be transferred. With the advancement of technology, by adopting new standards and solutions, it has become possible to transfer funds in real-time, without any delay, therefore the risk for the mershant in this case is reduced to a minimum. In addition to instant payments, when necessary, users have the opportunity to ask their banks to initiate payments on a customized schedule, by instructing them when and how much funds to transfer from their accounts to the accounts of others.

One of the most popular online payment methods that is widely used today is PayPal. PayPal is a payment service that allows e-mail money transfer and requires only the user's email and one active current account or payment card for registration and usage (Vuksanović, Tomić, 2014). This service operates as an online payment intermediary for which it charges a fee. The advantage of using PayPal is reflected in its simplicity, since users have to enter account number or payment card information only during registration and they make all further payments using only their passwords, without the need to re-enter all the information again. When making payments, funds are transferred from the payer's account to the PayPal account of the recipient, who can withdraw the funds from there to their bank account or use them for some future payment directly from their PayPal account. Different laws regulate this payment system in different ways, therefore, it is important to reduce regulatory diversity in order to make this payment system available to as many users in countries all over the world.

Micropayment systems can be used for small transaction values. Micropayment systems have been developed for transactions of less than $\$ 10$, which are too small for conventional credit card payments (Jovanović, Milovanović, 2008). Digital or electronic cash is most often used for these purposes. It represents money in electronic form that can be exchanged on the Internet between the users themselves, and the users and those companies who accept it as a means of payment. In addition to digital cash, new types of systems for "small" purchases have been introduced. These systems record all "small" values of the transactions incurred during a certain period of time, most often within a month, and charge this amount to a customer's credit card.

Besides these payment methods, there are many more ways to pay online, and as technology continues to develop, there is no doubt that they will be more numerous and more efficient. Since the use of mobile devices for making online transactions is increasing, the latest trends in the development of electronic payment systems are moving towards the development of payment applications for mobile phones and tablets. When it comes to methods of electronic payment, it is necessary that they are safe, so the 
users can rest assured that their funds will not fall into the wrong hands. Data privacy is also very important because confidential information related to account numbers, credit cards, conducted transactions, and personal data should not be accessible to everyone and abused in any way.

\section{Challenges and problems of international trade in digital space}

The development of new technologies has enabled access to a wide range of information, positively influenced the economic development of many countries and completely changed the way international trade functions. For a relatively short period of time, the Internet has turned from the media into a multidimensional market that connects an enormous number of participants. Nevertheless, in addition to numerous benefits, technological revolution has brought new challenges and difficulties at the same time. Violation of privacy, confidential data theft, fraudulent websites and unauthorized access to private accounts are just some of the current threats that users need to be wary of, therefore the authorities are trying to provide certain security measures in order to protect Internet users. However, since such measures can often limit the access of individuals and companies to the Internet and prevent the free exchange of information, the freedom of use that the Internet provides is brought into question.

Since the Internet has become a widely used business platform, many businessrelated legal issues have to be regulated in the digital space as well. In such cases, the interference of the authorities is completely legitimate, and even desirable, because Internet users need to be guaranteed security when making transactions. Nevertheless, the governments often block Internet access and data flow, filter information, and prohibit the display of certain content for political and many other unjustified reasons. Such measures of governments very often consciously promote domestic companies, at the same time causing damage to foreign business entities, denying them free access to the local market and customers. These issues need to be tackled globally, precisely because of the controversial interventions of state authorities, which restrict access to the Internet, and the impact of such measures on international trade. This way it would be possible to define specific cases in which government interventions are justified and to what extent. Such measures would improve trust in the Internet as a business environment and in its role as a driver of international trade.

One of the main concerns of the authorities is to ensure the adequate protection of electronic data of individuals. Nevertheless, countries may take different approaches to protecting customer privacy and cross-border data transfer. Most often, they design certain regulations that create a framework of behavior for companies that collect and use personal information of the consumers. The European Union, by the laws on data protection, prevents the transfer of consumer data to countries that don't provide an adequate level of data protection ${ }^{5}$. Such a solution has led to the necessary harmonization of laws in all Member States and has significantly affected the exchange of data with third

\footnotetext{
${ }^{5}$ Directive (EC) 95/46/EC of the European Parliament and of the Council of 24 October 1995 on the Protection of individuals with regard to the processing of personal data and on the free movement of such data
} 
countries. This can have a major impact on the operations of companies from non-EU countries, especially in the service sector where it is impossible to provide certain types of services that require personal data of consumers from the European Union. Moreover, the attitude of consumers towards their privacy can also substantially vary from country to country. For example, Germany has much stricter regulation than many other countries when it comes to email marketing and other online activities that companies often use, and most German consumers do not want to get promotional content unless they consent to it first.

Apart from the privacy and user protection issues, many other problems present in the global environment hinder the growth of international trade. Despite the significant and rapid advancement of e-commerce, there are still many difficulties that represent an obstacle to further development, especially in some less developed parts of the world. Although one of the biggest advantages of new technologies is that they're constantly becoming cheaper and more available, and the costs of implementing and using them are getting lower as the time is passing by, it seems that undeveloped countries still cannot afford the latest technology solutions and cannot catch up with the leading forces. The differences in the level of digitization and technological advancement between developed and developing countries are still significant. Although the Internet is a widespread and its use is growing day by day, a large number of people, as well as smaller companies, still do not have a stable Internet connection.

As recent years have witnessed the increasing use of wireless devices for accessing the Internet, the availability of mobile phones and the diffusion of mobile networks have become a prerequisite for the further expansion of the Internet user base (Meltzer, 2014). This particularly applies to developing countries where there is plenty of room for improvement of these conditions, given that the prices of smartphones are still high for the local population, and mobile telecommunication networks are underdeveloped. Broadband Internet access, which implies a stable connection and high data flow rate, is required for companies that want to engage in global supply chains and international trade over the Internet. In many developing countries, the use of this kind of connection is extremely low, usually because of the high costs, especially in those countries where the telecommunications market is monopolized.

In addition, a large proportion of consumers, primarily the elderly, remain skeptical about conducting transactions over the Internet, particularly when it comes to e-payments. Whether they'll decide to shop online or not depends on whether they are willing to accept the risk involved. Some of the main reasons for avoiding this method of buying are the inability to inspect the product and determine its quality, distrusting the seller, and the lack of guarantee that customers can return products if they do not meet their expectations. Moreover, since customers need to give their personal data and information related to their financials in order to make a payment, the willingness to carry out such an action decreases.

The lack of digital literacy and basic knowledge for conducting transactions online represents an obstacle for many consumers and sellers to get involved in this type of trade. A large number of people, especially in undeveloped countries, still lack the opportunity to acquire the appropriate digital education, and remain focused on traditional forms of trade. Similarly, many traders, insufficiently informed and prepared to adopt new technologies, stick to traditional business models without the possibility to 
reap all the benefits that e-commerce provides. For these reasons, besides the widespread access to the Internet and stable connections, in order to exploit the full potential of technology in international trade, it is very important to enable the population to get adequately trained and acquire knowledge and skills necessary for digital business. This primarily implies skill in handling computer equipment, knowledge of basic software programs, but also selecting the appropriate business model in the virtual space, integrating all logistical processes, managing the network of business partners and many other activities. Manufacturers and vendors wishing to engage in international online trade flows need to know how to get all relevant information about the foreign market they are entering, get familiar with administrative procedures and requirements, decide how to present their products and services and learn how to reach the potential customers in the most efficient way.

Inadequate logistics systems represent another obstacle to greater involvement in international trade, especially for undeveloped and developing countries. Trade logistics refers to all the processes and services that are necessary to transfer goods from one country to another. It includes transportation system such as ports, roads and airports, technological infrastructure and logistics services such as express delivery services, freight forwarding and traditional postal services (Meltzer, 2014). Most online transactions involve physical delivery of goods, which requires a developed transportation system, a widespread distribution network and well-functioning customs procedures. Inefficient and costly transport, high administrative costs and delivery delays are some of the major problems that many developing countries are facing, which make it difficult for them to enter global supply chains and engage in international trade.

\section{Conclusion}

The impact of technology on today's society as a whole is enormous. There is almost no segment in the life of an individual or in business operations which is not affected by modern technologies, at least indirectly, if not directly. Innovation in the field of information and communications technologies has a dominant role in the shaping of the global economy and international trade relations. Since physical barriers and distance problems can be overcome successfully, communication can be achieved without difficulty and data can be collected and processed easily, with significantly lower costs, the world market has become available to almost everyone, and getting involved in international trade flows much faster and less complicated.

The Internet is becoming the primary platform for conducting international transactions. Companies can easily reach a large number of potential customers, more than they could ever before, and access to new, far-off markets is practically unlimited. Entering an unknown market once demanded significant financial resources, implied complicated procedures, and was a long process. However, today this can be done remarkably faster, with much lower costs and in a more successful way. This has created an opportunity for small and medium-sized companies to engage in international trade, which was once possible only for powerful multinational companies. The development of information and communications technologies has significantly improved communication, enabled better connectivity and more efficient coordination of business 
entities located in different locations. Moreover, the process of production is becoming extremely fragmented, and supply chains are gaining global dimensions. The ability to interact with website and online store visitors has provided manufacturers and vendors with the opportunity to get to know the needs, preferences and habits of their customers in the most efficient way and to successfully respond to their demands. Personalized content, which matches the interests of a particular customer, increases the likelihood of sales, and allowing customers to design products the way they want improves their satisfaction.

The increasing importance of data exchange in international environment and the significant impact of the Internet on international trade require the adoption of common measures and the introduction of appropriate regulations to support further penetration of technology into the global economy. In order to maximize the benefits of technology in international trade, problems related to the wider diffusion and easier access to a fast and stable Internet connection must be solved, users' privacy and a safe use of their personal data must be guaranteed and adequate logistics systems must be constructed. E-commerce is particularly significant for underdeveloped countries, which in this way can successfully engage in international trade flows. However, in order to achieve this, they must improve their infrastructure, enable uninterrupted Internet access, encourage the population to acquire knowledge in the field of technology and establish efficient procedures for conducting electronic transactions.

Finally, the further development and expansion of information and communications technologies will significantly affect international trade in the following period. Not only can we expect a further reduction in the cost of data collection, data processing and communication, which will facilitate trade in the global environment to the greater extent, but it also seems inevitable that further changes will occur in the trade process and its structure as well. Online transactions will be even more numerous, the share of e-commerce considerably greater and the engagement of small and medium-sized enterprises in international trade increased.

\section{References}

Abelianskya, A. \& Hilbert, M. (2017) Digital technology and international trade: Is it the quantity of subscriptions or the quality of data speed that matters?, Telecommunications Policy 41, 35-48

Choi, C. (2010). The effect of the Internet on service trade, Economics Letters 109: $102-104$.

Clarke, G. R. G. \& Wallsten, J. S. (2006). Has the Internet Increased Trade? Developed and Developing Country Evidence, Economic Inquiry 44, No. 3: 465-484.

Directive (EC) 95/46/EC of the European Parliament and of the Council of 24 October 1995 on the Protection of individuals with regard to the processing of personal data and on the free movement of such data

Đorđević, G. (2012). Uticaj ICT informacionog društva na društveno - ekonomski razvoj, Socioeconomica - The Scientific Journal for Theory and Practice of Socioeconomic Development Vol. 1, N², pp. $188-200$. 
Freund, C. \& Weinhold, D. (2002). The Internet and International Trade in Services, The American Economic Review 92(2): 236-240.

Freund, C. \& Weinhold, D. (2004). The effect of the Internet on international trade, Journal of International Economics 62: 171 - 189.

Global B2C Ecommerce Report Light 2017

http://www.internetworldstats.com/stats.htm

Jovanović, R. \& Milovanović, S. (2008). Upravljanje elektronskim poslovanjem, Ekonomski fakultet, Niš

Kalakota, R. \& Whinston, A.B. (1996). Electronic commerce: a manager's guide, Addison Wesley Publishing, London

Liu, L. \& Nath, H. (2013). Information and Communications Technology (ICT) and Trade in Emerging Market Economies, Emerging Market Finance and Trade, 49, 6, 67-87.

Lupu, S., Mual, M. \& van Stiphout, M. (2016). Ecommerce Payment Methods Report, The Paypers BV

Meltzer, J. (2014). Supporting the internet as a platform for international trade: Opportunities for small and medium-sized enterprises and developing countries, Working paper 69, Global Economy \& Development program, Brookings Institution, Washington

Meltzer, J. (2016). Maximizing the Opportunities of the Internet for International Trade. E15 Expert Group on the Digital Economy - Policy Options Paper. E15Initiative. Geneva: International Centre for Trade and Sustainable Development (ICTSD) and World Economic Forum.

Nath, H. \& Liu, L. (2017). Information and communications technology (ICT) and services trade, Information Economics and Policy, North-Holland

R.V. (2016). E-trgovina: Klikom do kupovine, Nedeljnik Vreme 1356-7.

OECD Guide to Measuring the Information Society (2011).

OECD/WTO (2013). Aid for trade and value chains in information and communication technologies, Paris: OECD; Geneva: WTO

PwC (2016). They say they want a revolution, Total Retail 2016

Spulber, D. F., (2010). The map of commerce: Internet search, competition and the circular flow of information. Journal of Competition Law \& Economics, 5(4), pp. 633-682.

Treese, G.W. \& Stewart, L.C. (1998). Designing systems for Internet commerce, London: Addison-Wesley

Vemuri, V. K. \& Siddiqi, S. (2009). Impact of Commercialization of the Internet on International Trade: A Panel Study Using the Extended Gravity Model, The International Trade Journal 23, No. 4: 458 - 484.

Vuksanović, E. \& Tomić, N. (2014). Alternativni mehanizmi plaćanja u elektronskoj trgovini; Uticaj Interneta na poslovanje u Srbiji i svetu, Sinteza, 153-159.

Xing, Z. (2017). The impacts of Information and Communications Technology (ICT) and E-commerce on bilateral trade flows, International Economics and Economic Policy. 1-22. 10.1007/s10368-017-0375-5. 